\title{
Inquiry-Scaffolding Learning Model: Its Effect on Critical Thinking Skills and Conceptual Understanding
}

\author{
Wartono $^{1}$, Yohana Fransiska Alfroni ${ }^{2}$, John Rafafy Batlolona ${ }^{3 *}$, Natcha Mahapoonyanont ${ }^{4}$ \\ ${ }^{1,2}$ Physics Education Study Program, Faculty of Science and Technology, Universitas Kanjuruhan Malang, \\ Malang, Indonesia \\ ${ }^{3}$ Teacher Professional Education Study Program, Faculty of Teacher Training and Education, Universitas \\ Pattimura, Ambon, Indonesia \\ ${ }^{4}$ Educational Faculty, Thaksin University, Songkhla Campus, Thailand
}

*Corresponding Address: johanbatlolona@gmail.com

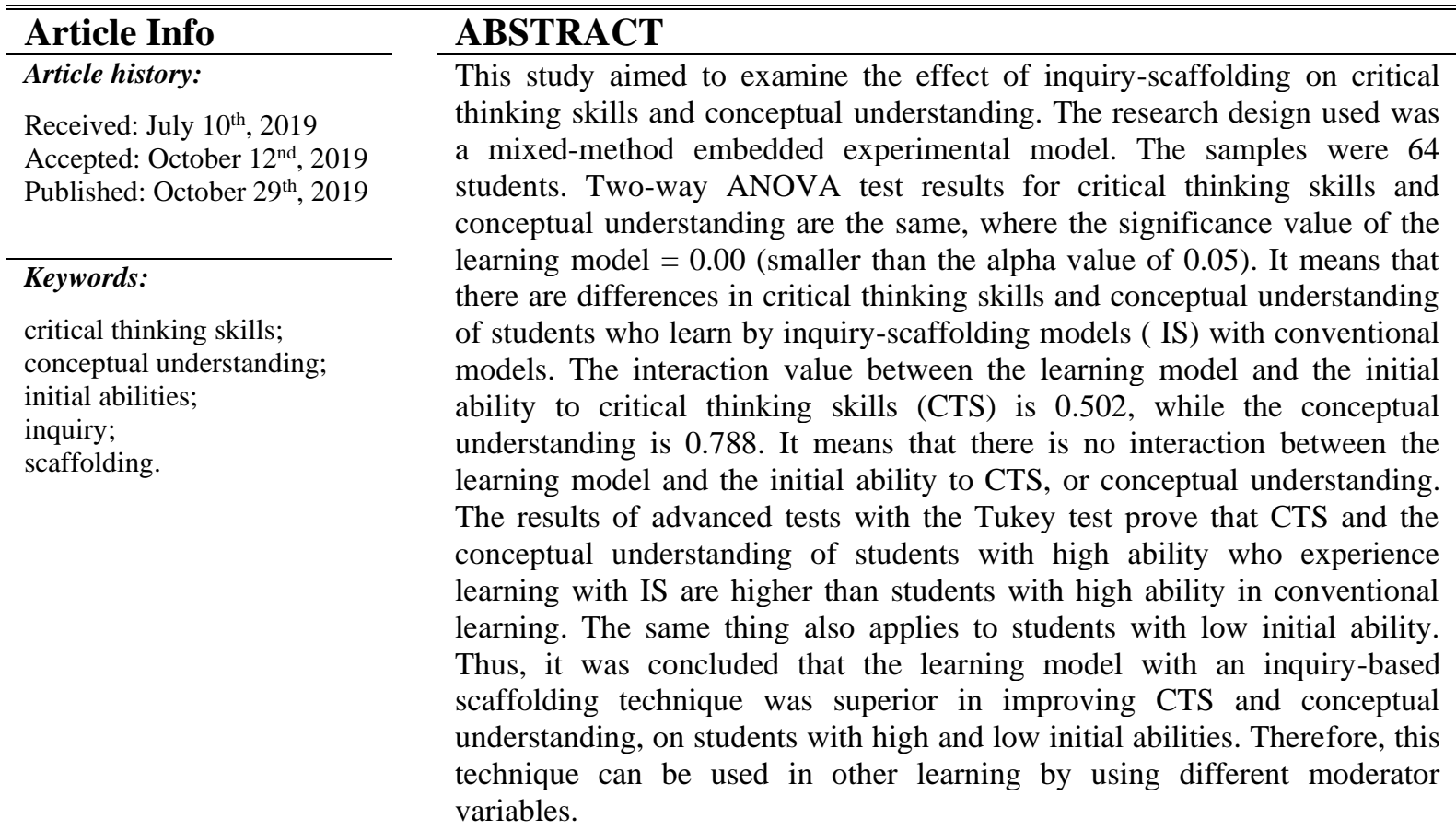

(C) 2019 Physics Education Department, UIN Raden Intan Lampung, Indonesia

\section{INTRODUCTION}

Learning physics is considered by many students and almost everyone is a field of science that requires a good conceptual understanding that trains students to think constructively, analytically, logically, and systematically (Shishigu, Hailu, \& Anibo, 2018; Latifah et al., 2019). The experts explain that learning physics is one of the sciences that is considered very difficult, especially because learning is oriented towards various representations that are still abstract (Klein, Viiri, \& Kuhn, 2019).

The main objective of learning physics in the current era is to provide knowledge experience, practice critical and creative thinking skills and be able to produce innovative work (Whiley, Witt, Colvin, Sapiains Arrue, \& Kotir, 2017). In constructing the reconstruction of knowledge, brilliant thinking and analysis are needed in the form of critical issues to correct conceptual errors that are still 
wrong, to fit the views of experts. (Doleck, Bazelais, Lemay, Saxena, \& Basnet, 2017). Critical thinking cannot be obtained easily, therefore it takes a lot of intellectual exercise in reconstructing the brain to think. Critical thinking skills (CTS) train students to conduct investigations, analyze information and reflect. Furthermore, CTS is also a basic skill needed in the world of work including decision making, leadership and scientific reasoning so that it leads to professional success (Kola, 2019). The results of research in Hong Kong explained that the student learning environment greatly influences student CTS. Therefore, critical thinking plays a role in mediation, related to the relationship of the learning environment, conceptual understanding, and academic skills of students (Tiruneh et al., 2016).

The research report provides information that students' critical thinking skills are still very low. As evidenced by the results of research in several cities in Indonesia, including in Ambon (Leasa, Talakua, \& Batlolona, 2016), Malang (Mahanal, Zubaidah, Sumiati, Sari, \& Ismirawati, 2019), Semarang (Muhlisin, Susilo, Amin, \& \& Rohman, 2016) and Karas City (Irwan, Maridi, \& Dwiastuti, 2019). Also, in several countries in the world, among others, Turkey, which has entered the category of developed country (El Soufi \& See, 2019) and several developing countries such as Vietnam (Das, Nguyen, Nguyen, Nomikoudis, \& Van, 2019) and Thailand (Ruchiwit, Patchotasingh, \& Phanphairoj, 2019).

CTS is very much related to conceptual understanding. Conceptual understanding is needed as a basis for solving problems, thinking critically and creatively. Specifically, that conceptual understanding transforms knowledge into multiple representations so that new concepts are born (Kadir, Yeung, \& Diallo, 2017). A person in achieving high levels of thinking is built from the foundation of a conceptual. Therefore, in improving CTS, it is necessary to hone cognitive knowledge by building internal conceptual. The teacher as a facilitator in learning, need to consider the initial ability of students that will facilitate in accommodating students so that learning objectives will be achieved (Kruit, Oostdam, van den Berg, \& Schuitema, 2018).

The results of previous studies inform that the level of students' conceptual understanding of physics is still very low because teachers give a lack of training in students' critical thinking skills (Dwyer, Hogan, Harney, \& Kavanagh, 2017). Besides, in the learning process, teachers tend to pay less attention to the initial abilities of students. Poor conceptual understanding will cause students' CTS levels to also below (Tseng, 2019).

Besides paying attention to initial abilities, the teacher also needs to choose the right learning model in improving CTS and students' conceptual understanding. One recommended learning model is the inquiry learning model since it offers studentcentered (Fernandez, 2017). Experts develop inquiry learning models to improve students' innovation skills in thinking and solving problems (Acar \& Tuncdogan, 2018). Inquiry learning requires students to work collaboratively in asking questions, making temporary hypotheses, designing an investigation, developing results and findings in accordance with what is obtained and building communication (Suárez, Specht, Prinsen, Kalz, \& Ternier, 2018). In improving CTS and students' conceptual understanding, scaffolding techniques are used in its application. This is because scaffolding can motivate students to learn (Hsu, Lai, \& Hsu, 2015). Scaffolding technique as one of the aids in accordance with the physics learning characteristics to practice new skills in solving physical problems that are considered difficult (Dawkins, Hedgeland, \& Jordan, 2017). By scaffolding-assisted learning, students get more detailed directions and instructions from the teacher at the time of learning, so that patterns of interaction are more directed 
in achieving the objectives to be achieved. Learning assistance is an indispensable thing. This is because the composition of students in the class varies from aspects of cognitive abilities. This assistance is given to students in accordance with the level of ability seen from the initial ability of students.

One of the recommended learning models is an inquiry with scaffolding techniques. Based on the results of previous studies, many experts have developed similar studies but with a different focus. Researches by examining the effect of Inquiry-scaffolding (IS) on students' critical and conceptual thinking skills are still limited. They are still being developed with different variables between inquiry and CTS (Mercuri \& Mercuri, 2019), IS to improve scientific argumentation (Andrews-Larson, McCrackin, \& Kasper, 2019) and IS to increase critical thinking in asking scientific questions (Brownfield \& Wilkinson, 2018). Thus, a deeper exploration of this problem was carried out. Therefore, the purpose of this study was to analyze the effect of the Inquiry-scaffolding learning model on the critical thinking ability and physics conceptual understanding of students on static fluid material.

\section{METHODS}

The research method used was a mixedmethod embedded experimental model to explore the research subject completely. The research design can be shown in Figure 1. The study was conducted in one of the medium level schools based on the categorization of the Malang City Education Office. One of the reasons for choosing the school is because of the heterogeneous characteristics of students without an entrance test to get students who excel when graduating from elementary school. The samples in this study were 64 students consisting of 23 male students and 41 female students. The study was conducted in class VIII at Public Junior High School 3 Malang. To measure critical thinking skills and conceptual understanding, two classes were used. Class VIII 5 is as an experimental class that was named as "Pascal" with 32 students and VIII 6 as a control class that was named "Archimedes" with 32 students. The technique used in research sampling was purposive sampling. Through preliminary tests in the Pascal and Archimedes classes, it was proven that students had the same initial abilities.

The instrument used for research to measure student CTS was in the form of a test item with 10 items with a score level of 0-5 with a clear description of the answers. The questions for conceptual understanding used a multiple-choice test pattern of 20 items. The technique used in data collection was in the form of in-depth interviews related to student answers and confirmed learning patterns with IS. In each meeting, observations were made on the feasibility of learning and the material being taught. The documentation of student activities from the pretest and the learning process of each meeting to the posttest was used. The data analysis technique used was a two-way ANOVA test with the assistance of SPSS 16.0 for Windows. Before testing the hypothesis, the requirements that are met are normality and homogeneity testing with the Kolmogorov-Smirnov test with the assistance of SPSS 16.0 for Windows. The following is a research flow chart shown in Figure 1. 


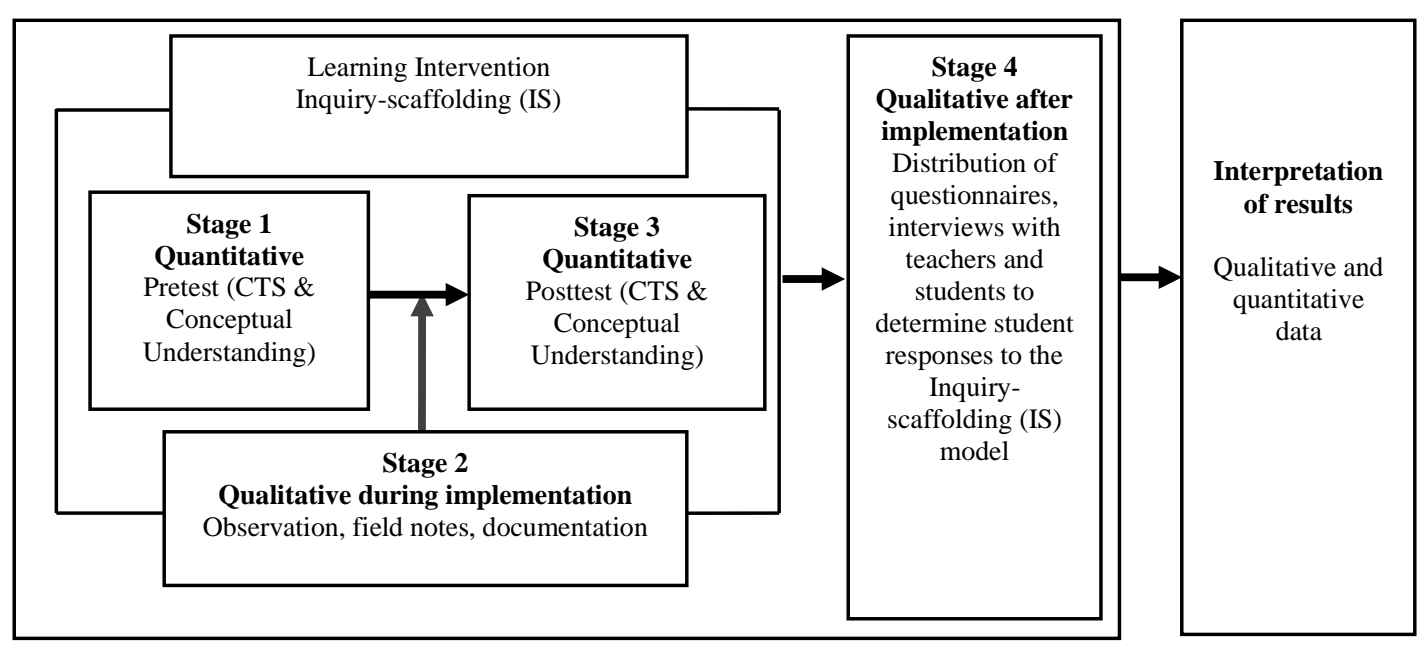

Figure 1. Research design

\section{RESULTS AND DISCUSSION}

The pretest and posttest scores in the Pascal class to measure critical thinking skills (CTS) and conceptual understanding (CU) before and after were given in-depth to students. The learning material was static fluids as shown in Table 1.

Table 1. Description of Pascal and Archimedes class

\begin{tabular}{|c|c|c|c|c|}
\hline \multirow{2}{*}{$\begin{array}{l}\text { Measuring } \\
\text { variable }\end{array}$} & \multicolumn{2}{|c|}{ Pascal } & \multicolumn{2}{|c|}{ Archimedes } \\
\hline & $\begin{array}{l}\text { Pre } \\
\text { test }\end{array}$ & $\begin{array}{c}\text { Post } \\
\text { test }\end{array}$ & $\begin{array}{l}\text { Pre } \\
\text { test }\end{array}$ & $\begin{array}{c}\text { Post } \\
\text { test }\end{array}$ \\
\hline CTS & 36.84 & 79.21 & 37.09 & 67.34 \\
\hline $\mathrm{CU}$ & 36.71 & 77.81 & 46.25 & 68.59 \\
\hline
\end{tabular}

The results of Table 1 show that there are differences in CTS and CU of students in the Pascal and Archimedes classes. The Pascal class is higher than the Archimedes class. The findings found that students feel more helped in their learning with IS. Students find good learning patterns to stimulate CTS and CU. At the beginning of learning, students still felt confused. At the next meeting, students were so enthusiastic about learning. Students' CTS and CU increase at the posttest after being given treatment. It means that the learning models and techniques applied to the learning process affected CTS and CU. The IS model can increase conceptual understanding because the model requires students to learn to find by themselves to gain more knowledge by giving a problem and solve it based on the knowledge they have (Diani et al., 2018). When students experience difficulties in learning, it is necessary to have scaffolding, as a medium that aims to help students who have learning difficulties so that they can solve a problem. This is proven by the N-Gain of student scores shown in Figure 2.

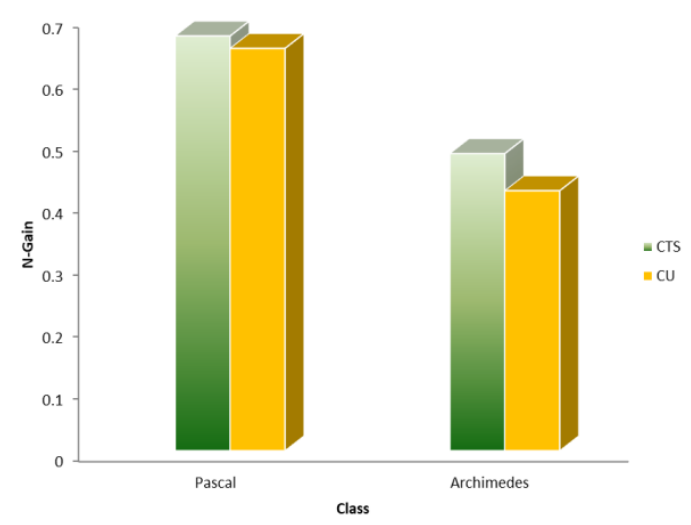

Figure 2. N-Gain of CTS and CU in Pascal and Archimedes classes

The data tested is the posttest data to test the hypothesis using the two-way ANOVA test. The N-Gain Test using the Independent Sample Test was used to see improvements in CTS and conceptual understanding before and after treatment.

The results of the normality test sample data showed that conceptual understanding's significance coefficient of the experimental 
class was 0.661 , the critical thinking with significance coefficient of 0.925 , the conceptual understanding of control class with significance coefficient of 0.282 , and the critical thinking of the control class with significance coefficient of 0.879 . Thus, it can be said that the data were normally distributed since they were greater than 0.05 . Homogeneity test results between the sample data in this study showed that a significance coefficient of 0.780 for conceptual understanding and 0.169 for the CTS. Based on the results, it shows that the data were homogeneous with the analysis result is greater than 0.05 . The data in this study have fulfilled the prerequisite test. The sample data were normally distributed and came from a homogeneous group. Therefore, the data was then tested in advanced. The advanced test results are explained in the description form.

The results of the hypothesis test are as follows.

\section{Hypothesis 1}

Hypothesis 1 in this study was analyzed using the two-way ANOVA statistical test.

The coefficient of significance got 0,000 or sig $<0.05$ so $\mathrm{H} 0$ was rejected or $\mathrm{H} 1$ was accepted. There were differences between the CTS of students who learned with the IS model and conventional learning.

2. Hypothesis 2

The significance coefficient got 0.502 or sig> 0.05 so that $\mathrm{H} 0$ was accepted or $\mathrm{H} 1$ was rejected, so it was concluded that there was no interaction between IS and initial ability of CTS.

3. Hypothesis 3

The third hypothesis test in this study used the Post Hoc advanced test. The significance coefficient got 0.013 or sig $<0.05$ so $\mathrm{H} 0$ is rejected or $\mathrm{H} 1$ is accepted. This means that CTS students with high initial abilities who learned by using the IS model were higher than students with high initial abilities who learned using conventional learning.

\section{Hypothesis 4}

The fourth hypothesis test in this study used the Post Hoc advanced test. The significance coefficient got 0.013 or sig $<0.05$ so $\mathrm{H} 0$ was rejected or $\mathrm{H} 1$ was accepted. Thus, CTS students with low initial abilities who learned using the IS model were higher than students with low initial abilities who learned using conventional learning.

5. Hypothesis 5

The coefficient of significance got 0,000 or sig $<0.05$ so $\mathrm{H} 0$ was rejected or $\mathrm{H} 1$ was accepted. In conclusion, there was a difference in the conceptual understanding of students who learned with the IS model and conventional learning.

6. Hypothesis 6

The significance coefficient got 0.788 or sig> 0.05 so H0 was accepted or H1 was rejected. In conclusion, there was no interaction between IS and initial ability to students' physics conceptual understanding.

7. Hypothesis 7

The seventh hypothesis test in this study used the Post Hoc advanced test. The significance coefficient got 0.013 or sig $<0.05$ so $\mathrm{H} 0$ was rejected or $\mathrm{H} 1$ was accepted. It means that the physics conceptual understanding of students with high initial abilities who learned using IS was higher than students with high initial abilities who used conventional learning.

8. Hypothesis 8

The eighth hypothesis test in this study used the Post Hoc advanced test. The significance coefficient got 0.006 so $\mathrm{H} 0$ was rejected or $\mathrm{H} 1$ was accepted. Thus, the physics conceptual understanding of students with low initial abilities who learned using IS was higher than students with low initial abilities using conventional learning. 


\section{N-Gain Test Analysis Results for Student CTS.}

The results of the Independent Sample Test show that the significance coefficient value was less than 0.05 ( $\mathrm{sig}<0.05$ ), which was 0.000 so that it can be concluded that there was a very significant difference in the ability to think critically between students who learn using IS learning and students who learn using conventional learning. Independent Sample Test Results show the value of the coefficient of significance in the line between groups was smaller than 0.05 ( $\operatorname{sig}<0.05$ ) which was 0.007 so it can be concluded that there was a very significant difference in the ability of physics conceptual understanding between students who learned using IS and students who learned using conventional learning.

The success of IS in improving CTS and students' physics conceptual understanding was supported by steps of inquiry learning that involve students actively and collaboratively in learning so that students found the right formula. Also, scaffolding could help students in improving student CTS. Learning through a practicum in the IS occurs the interaction of discussions with groups to build cooperation and exchange opinions to solve the problems faced. Also, there was teacher assistance to direct and guide students so that learning was more directed and systematic. The learning process carried out to take place well when students are allowed to ask questions that are considered very important to build conceptual knowledge. Students felt valued and respected during the learning process. This pattern was a humanist learning process that makes simple learning more meaningful (Batlolona, Baskar, Kurnaz, \& Leasa, 2018).

Other findings also showed no interaction between the IS learning model and initial ability to CTS and students' physics conceptual understanding. Thus, it can be said that students with high initial abilities both those taught using IS and those who learned using conventional learning will still be higher than students with moderate initial abilities, and students with moderate initial abilities will still be higher than students with low initial abilities. Students with high initial ability had an intention from within oneself to study even harder, while students with low initial ability did not like physics because it was difficult. Also, some students explained that they preferred kinematics and electricity. They felt the material was very pleasant and the teacher's learning patterns were more detailed and related to digital learning that describes the concept. Students with high initial abilities tend to continue to improve their academic skills. The findings of previous experts explain that there is no interaction between the initial ability of students and learning models on student physics learning outcomes (Parappilly, Schmidt, \& Ritter, 2015).

The results showed that CTS and physics conceptual understanding of students with high initial abilities who learned using IS learning were higher than students with high initial abilities who learned using conventional learning. The increase of CTS and physics conceptual understanding of students with high initial abilities who learned by using IS learning was due to several factors. High initial ability students who learned using IS learning to tend to have their learning intentions and were supported by learning models that provide opportunities for students to play an active role in learning. Activities in IS learning required students to concentrate fully on learning. Students practiced solving problems independently to give direction to students to solve these problems. This was in accordance with the advantages of scaffolding, which helps students' failure in cognitive development.

The results showed that CTS and physics conceptual understanding of students with low initial abilities who learned using IS learning were higher than students with low initial abilities who learned using conventional learning. Low 
initial ability have the opportunity to play an active role. The phases in the inquiry learning model that were collecting data and testing hypotheses provided an opportunity for them to explore knowledge and discuss it with peers. Thus, forming students in understanding concepts, reconstructing new theories and looking for alternative solutions
Critical thinking skills were directed at high thinking. This can be seen in the recorded answers to students where they were able at a very critical level. Critical thinking was based on a good conceptual understanding.

Table 2. Results of recording answers with are learning to improve CTS and students' conceptual understanding

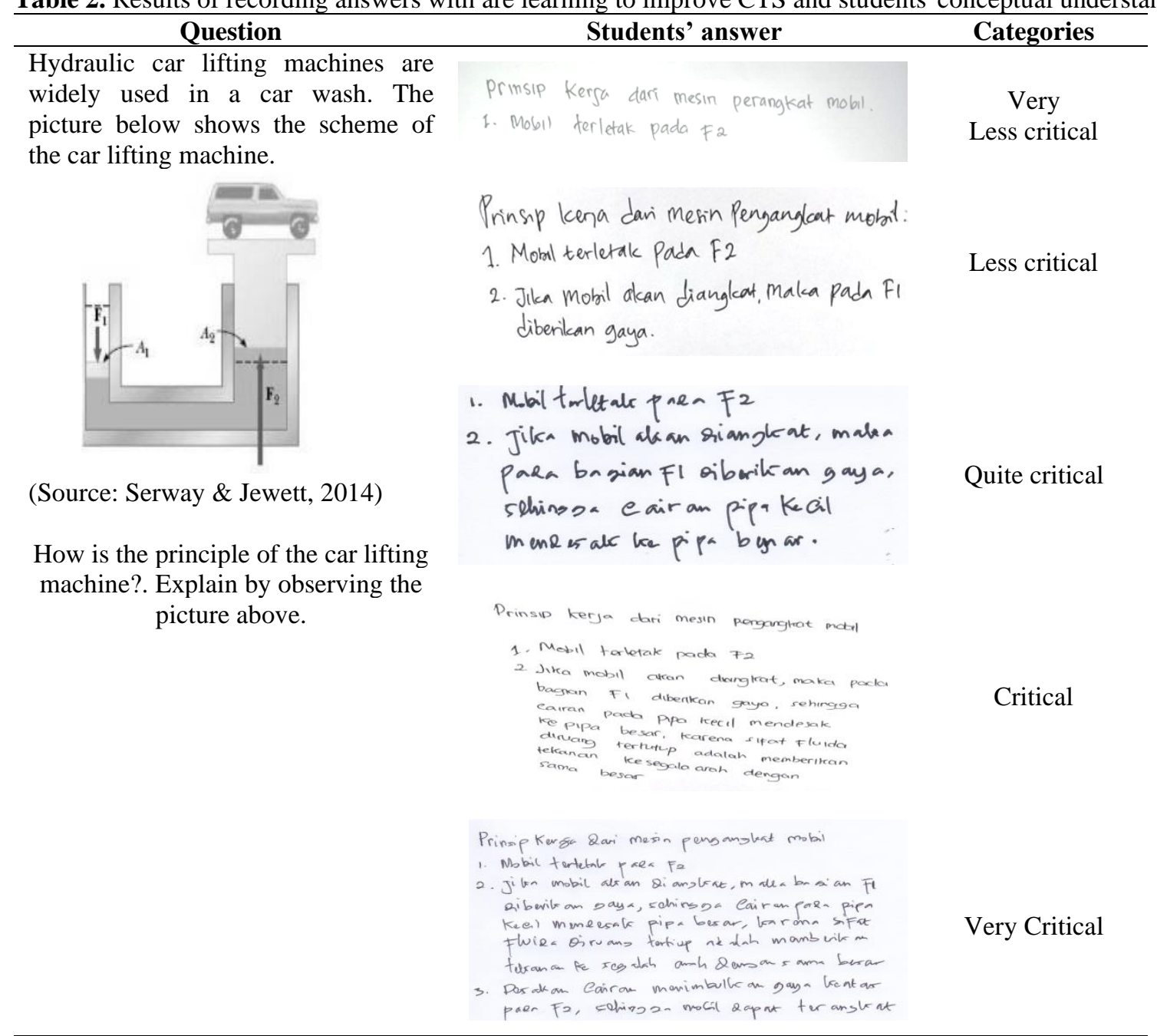

Assistance from the teacher as a guide, when making observations has a positive impact on the learning success of students who learned using IS. Also, sufficient practice exercises cause students to experience an increase in CTS grades and conceptual understanding. This was because inquiry facilitates students thinking at a high level in solving physics problems (Roksa et al., 2017). In the initial learning, in
Thailand, $36.5 \%$ of 6,235 students who were taught using conventional learning in 10 Provinces obtained the average score and only $2.09 \%$ of them passed. It is a relatively low achievement of learning outcomes. After approaching the inquiry, students experience a fairly high increase (Changwong, Sukkamart, \& Sisan, 2018). By the stages of learning and using scaffolding techniques, students felt helped 
in learning and got better ability to reconstruct physics conceptual.

Communication skills and alternative ideas could be provided by students. This was proven by the answers of students in Table 2. CTS students who learned using IS learning experienced significant success. This can be seen with a variety of students who answered with a good conceptual ranging from a very less critical level to very critical because of the assistance of scaffolding. Several reasons can be found that scaffolding provides a path for students to solve problems faced (Haruehansawasin \& Kiattikomol, 2017). Scaffolding can provide clearer direction that is clearer and does not confuse students 'thinking, because it helps students to easily understand the context of the problem while keeping students' focus on the basic concepts being studied. Also, it reduces the misconceptions that occur as a result of structured problem solving through more relevant basic concepts (Park, Tiwari, \& Neumann, 2019).

\section{CONCLUSION AND SUGGESTION}

The results of the study concluded that the learning model with inquiry-based scaffolding techniques was superior in improving CTS and understanding the concepts, in students with high and low initial abilities. Therefore, this technique can be used in other learning by using different moderator variables. Thus, it can be recommended that IS learning can improve critical thinking skills and students' physics conceptual understanding.

\section{AUTHOR CONTRIBUTIONS}

WW designed this research. YF made observations and collected data. JR performs statistical calculations. NM wrote the final script. All authors contributed to the creation of the research results.

\section{REFERENCES}

Acar, O. A., \& Tuncdogan, A. (2018). Using the inquiry-based learning approach to enhance student innovativeness: a conceptual model. Teaching in Higher

Education, $\quad O(0), \quad 1-15$.

https://doi.org/10.1080/13562517.2018. 1516636.

Andrews-Larson, C., McCrackin, S., \& Kasper, V. (2019). The next time around: scaffolding and shifts in argumentation in initial and subsequent implementations of inquiry-oriented instructional materials. Journal of Mathematical Behavior, (July 2018), 100719.

https://doi.org/10.1016/j.jmathb.2019.1 00719.

Batlolona, J. R., Baskar, C., Kurnaz, M. A., \& Leasa, M. (2018). The improvement of problem-solving skills and physics concept mastery on temperature and heat topic. Jurnal Pendidikan IPA Indonesia, 7(3), 273-279. https://doi.org/10.15294/jpii.v7i3.1243 2.

Brownfield, K., \& Wilkinson, I. A. G. (2018). Examining the impact of scaffolding on literacy learning: A critical examination of research and guidelines to advance the inquiry. International Journal of Educational Research, 90(October 2017), 177-190. https://doi.org/10.1016/j.ijer.2018.01.0 04.

Changwong, K., Sukkamart, A., \& Sisan, B. (2018). Critical thinking skill development: Analysis of a new learning management model for Thai high schools. Journal of International Studies, 11(2), 37-48. https://doi.org/10.14254/20718330.2018/11-2/3.

Das, A. K., Nguyen, Q. T., Nguyen, A. T., Nomikoudis, M., \& Van, D. H. (2019). Course redesign to incorporate flipped delivery: A business degree case in Vietnam. Issues in Educational Research, 29(2), 363-383.

Dawkins, H., Hedgeland, H., \& Jordan, S. (2017). Impact of scaffolding and question structure on the gender gap. Physical Review Physics Education 
Research,

13(2) https://doi.org/10.1103/PhysRevPhysE ducRes.13.020117.

Diani, R., Yuberti, \& Syarlisjiswan, M. R. (2018). Web-enhanced course based on problem-based learning (PBL): development of interactive learning media for basic physics II. Jurnal Ilmiah Pendidikan Fisika 'AlBiruni, 7(April), 107. https://doi.org/10.24042/jipfalbiruni. v7i1.2849

Doleck, T., Bazelais, P., Lemay, D. J., Saxena, A., \& Basnet, R. B. (2017). Algorithmic thinking, cooperativity, creativity, critical thinking, and problem solving: exploring the relationship between computational thinking skills and academic performance. Journal of Computers in Education, 4(4), 355-369. https://doi.org/10.1007/s40692-0170090-9.

Dwyer, C. P., Hogan, M. J., Harney, O. M., \& Kavanagh, C. (2017). Facilitating a student-educator conceptual model of dispositions towards critical thinking through interactive management. Educational Technology Research and Development, 65(1), 47-73. https://doi.org/10.1007/s11423-0169460-7.

El Soufi, N., \& See, B. H. (2019). Does explicit teaching of critical thinking improve critical thinking skills of English language learners in higher education? A critical review of causal evidence. Studies in Educational Evaluation, 60(August 2018), 140-162. https://doi.org/10.1016/j.stueduc.2018. 12.006 .

Fernandez, F. B. (2017). Action research in the physics classroom: the impact of authentic, inquiry based learning or instruction on the learning of thermal physics. Asia-Pacific Science Education, $3(1)$. https://doi.org/10.1186/s41029-0170014-z.
Haruehansawasin, S., \& Kiattikomol, P. (2017). Scaffolding in problem-based learning for low- achieving learners. The Journal of Educational Research, $O(0)$, $1-8$. https://doi.org/10.1080/00220671.2017. 1287045.

Hsu, Y. S., Lai, T. L., \& Hsu, W. H. (2015). A Design Model of Distributed Scaffolding for Inquiry-Based Learning. Research in Science Education, 45(2), 241-273. https://doi.org/10.1007/s11165-0149421-2.

Irwan, I., Maridi, M., \& Dwiastuti, S. (2019). Developing guided inquirybased ecosystem module to improve students' critical thinking skills. Jurnal Pendidikan Biologi Indonesia, 5(1), 51-60.

https://doi.org/10.22219/jpbi.v5i1.7287

Kadir, M. S., Yeung, A. S., \& Diallo, T. M. O. (2017). Simultaneous testing of four decades of academic self-concept models. Contemporary Educational Psychology, 51, 429-446. https://doi.org/10.1016/j.cedpsych.2017 .09.008.

Klein, P., Viiri, J., \& Kuhn, J. (2019). Visual cues improve students' understanding of divergence and curl: Evidence from eye movements during reading and problem solving. Physical Review Physics Education Research, 15(1), 10126. https://doi.org/10.1103/PhysRevPhysE ducRes.15.010126.

Kola, M. (2019). Grade 9 Technology Teachers' Explication of Critical Thinking and its Enactment in the Classroom. African Journal of Research in Mathematics, Science and Technology Education, O(0), 1-12. https://doi.org/10.1080/18117295.2019. 1601457.

Kruit, P. M., Oostdam, R. J., van den Berg, E., \& Schuitema, J. A. (2018). Assessing students' ability in 
performing scientific inquiry: instruments for measuring science skills in primary education. Research in Science and Technological Education, 36(4), 413-439. https://doi.org/10.1080/02635143.2017. 1421530

Latifah, S., Irwandani, I., Saregar, A., Diani, R., Fiani, O., Widayanti, W., \& Deta U. A. (2019). How the PredictObserve-Explain (POE) learning strategy remediates students' misconception on Temperature and Heat materials? In Seminar Nasional Fisika (SNF) 2018 (1-6). IOP Conf. Series: Journal of Physics: Conf. Series 1171. https://doi.org/10.1088/17426596/1171/1/012051

Leasa, M., Talakua, M., \& Batlolona, J. R. (2016). The development of a thematic module based on Numbered Heads Together (NHT) cooperative learning model for elementary students in Ambon, Moluccas-Indonesia. New Educational Review, 46(4). https://doi.org/10.15804/tner.2016.46.4 .15 .

Mahanal, S., Zubaidah, S., Sumiati, I. D., Sari, T. M., \& Ismirawati, N. (2019). RICOSRE: A learning model to develop critical thinking skills for students with different academic abilities. International Journal of Instruction, 12(2), 417-434. https://doi.org/10.29333/iji.2019.12227 a.

Mercuri, S., \& Mercuri, N. (2019). Scaffolding English Language Learners' Literacy Development Through a Science Inquiry Approach. 231-245. https://doi.org/10.1007/9783-030-02245-7_15.

Muhlisin, A., Susilo, H., Amin, M., \& Rohman, F. (2016). Improving critical thinking skills of college students through RMS model for learning basic concepts in science. Asia-Pacific Forum on Science Learning and Teaching, 17(1).
Parappilly, M., Schmidt, L., \& Ritter, S. De. (2015). Ready to learn physics: A team-based learning model for first year university. European Journal of Physics, $36(5)$. https://doi.org/10.1088/01430807/36/5/055052.

Park, M., Tiwari, A., \& Neumann, J. W. (2019). Emotional scaffolding in early childhood education. 5698(May). https://doi.org/10.1080/03055698.2019. 1620692

Roksa, J., Trolian, T. L., Pascarella, E. T., Kilgo, C. A., Blaich, C., \& Wise, K. S. (2017). Racial Inequality in Critical Thinking Skills: The Role of Academic and Diversity Experiences. Research in Higher Education, 58(2), 119-140. https://doi.org/10.1007/s11162-0169423-1.

Ruchiwit, M., Patchotasingh, M., \& Phanphairoj, K. (2019). Strategies for Creating Innovators in Thailand's Higher Education. Journal of Medical Education and Curricular Development, 6, 238212051986307. https://doi.org/10.1177/2382120519863 078.

Serway, R. A., \& Jewett, J. W. (2004). Physics for scientists and engineers. Belmont, CA: ThomsonBrooks/Cole.

Shishigu, A., Hailu, A., \& Anibo, Z. (2018). Problem-based learning and conceptual understanding of college female students in physics. Eurasia Journal of Mathematics, Science and Technology Education, 14(1), 145-154. https://doi.org/10.12973/ejmste/78035.

Suárez, Á., Specht, M., Prinsen, F., Kalz, M., \& Ternier, S. (2018). A review of the types of mobile activities in mobile inquiry-based learning. Computers and Education, $\quad 118, \quad 38-55$. https://doi.org/10.1016/j.compedu.2017 .11.004.

Tiruneh, D. T., Weldeslassie, A. G., Kassa, A., Tefera, Z., De Cock, M., \& Elen, J. (2016). Systematic design of a learning 
environment for domain-specific and domain-general critical thinking skills. Educational Technology Research and Development, 64(3), 481-505. https://doi.org/10.1007/s11423-0159417-2.

Tseng, S. S. (2019). Using Concept Mapping Activities to Enhance Students' Critical Thinking Skills at a High School in Taiwan. Asia-Pacific Education Researcher. https://doi.org/10.1007/s40299-019-
00474-0.

Whiley, D., Witt, B., Colvin, R. M., Sapiains Arrue, R., \& Kotir, J. (2017). Enhancing critical thinking skills in first year environmental management students: a tale of curriculum design, application and reflection. Journal of Geography in Higher Education, 41(2), 166-181.

https://doi.org/10.1080/03098265.2017. 1290590. 